\title{
Sexual Harassment And Public Accounting: Anecdotal Evidence From The Profession
}

\author{
Gerald J. Miller, College of New Jersey, USA \\ Brian B. Stanko, Loyola University-Chicago, USA \\ Ellen L. Landgraf, Loyola University-Chicago, USA
}

\begin{abstract}
This article reports on anecdotal evidence gathered from a recent survey of women public accounting professionals. Stanko and Schneider (1999) conducted the first national survey on sexual harassment in the public accounting profession and Stanko et al followed up with a more recent 2009 study. In this paper, the anecdotal evidence gathered from the Stanko et al study is reported on. Analysis of written comments is important in that many respondents spent a great deal of time providing comprehensive and concise professional comments on specific recent experiences involving sexual harassment, rather than simply checking a box. The findings of this study show sexual harassment remains a serious concern, and that sexual discrimination in the workplace is a concern as well. Although preventive measures have been put in place, these measures may not be working as well as intended, suggesting that public accounting firms need to revisit this issue to manage risk.
\end{abstract}

Keywords: AICPA Rule 501-2; Certified Public Accountants; Civil Rights Act of 1991; EEOC; Sexual Harassment; Title Vll

\section{INTRODUCTION}

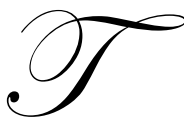

hirty years ago women were just beginning to enter the workforce in numbers large enough to make them visible. In 2007, women accounted for 46.4 percent of all employed workers and over fifty percent of the financial activities industry ${ }^{1}$. The changing gender of the United States workforce has forced employers to confront issues including sexual harassment as never before.

This homogenization of the workforce can be problematic. In fiscal year 2008 alone, the EEOC received 13,867 charges of sexual harassment of which 11,371 were resolved. This constitutes a 42\% increase since 1993. $\$ 47.4$ million in monetary benefits were recovered (not including monetary benefits obtained through litigation) for charging parties and other aggrieved individuals, and $84.1 \%$ of these charges were filed by women. Sexual harassment is no small problem; for employers, harassment carries immense costs even when a lawsuit is not filed. The cost to a typical Fortune 500 company (as reported by Working Women magazine) can amount to $\$ 6.7$ million a year in absenteeism, low productivity and employee turnover. Although $50 \%$ of the women who have experienced harassment at work say that they simply try to ignore it, these same women experience an average productivity decline of $10 \%$. About $24 \%$ of harassment victims take leave time to avoid the harasser, while $10 \%$ choose to leave their jobs. Thus, even a company which never goes through a sexual harassment lawsuit is paying a heavy price.

According to studies conducted in the U.S., 40 to 70 percent of women have been victims of some form of sexual harassment. For example:

- A 1990 poll by the National Association of Female Executives indicated that $77 \%$ believed sexual harassment to be a problem in the workplace.

\footnotetext{
${ }^{1}$ Current Population Survey, BLS Report 1011, Women in the labor Force: A Databook (2008 Edition.)
} 
- A 1991 survey of 524 firms by the American Management Association indicated that 52\% of the respondents had dealt with allegations of sexual harassment.

- $\quad$ A 1993 study of Sexual Harassment in Medical Training published in the New England Journal of Medicine indicated $73 \%$ of the female residents reported that they had been sexually harassed at least once during their training.

- A 1994 national survey of more than 8,000 Federal workers reported that 44\% of women respondents had experienced sexual harassment in the past two years.

\section{THE ACCOUNTING PROFESSION AND SEXUAL HARASSMENT}

The accounting profession has experienced a significant increase in the number of female entrants over the last several years. In 1992 the American Institute of Certified Public Accountants (AICPA) reported that women represented $50 \%$ of the accounting graduates. By 2004 this percentage had risen to $56 \%$ of the new entrants to the profession with public accounting continuing to be the employment leader for new graduates according to a 2005 AICPA ${ }^{2}$ study titled "A Decade of Changes in the Accounting Profession: Workforce Trends and Human Capital Practices." This study also indicated that at the partner level, females only represent $19 \%$ of partners on average with a low of $12 \%$ for larger firms and a high of $27 \%$ for the smallest firms. This is an indication that the public accounting profession is still male-dominated at the higher levels. The survey also included responses from individuals in business and industry and found that the two most common job titles for female respondents were Controller (24\%) and Financial/Accounting Manager (21\%). Male respondents were as likely to be CFOs (23\%) and Controllers (20\%). Only sixteen percent of men were Financial/Accounting Managers. Although women tend to fare better in business/industry, it appears that client(s) of public accounting firms are also more likely to be maledominated at the CFO level.

The existence of large power differentials among organization levels in highly structured bureaucratic organizations has been found to be an indication that the organization is more prone to higher levels of sexual harassment incidence (Ilies et al, 2003, Berdahl, 2007..$^{3}$ ) Additional evidence that women employed in public accounting report that they and/or their female colleagues are victims of sexual harassment and gender-based discrimination was found by Ilies et al 2003, Stanko and Schneider, 1999 and Stanko et al, $2009 . \quad$ Public accounting firms should be cognizant of these research conclusions. Sexual harassment litigation is a no win game-certainly the victim suffers and the company faces financial risk as well as loss of reputation. One only has to look to the popular press for an account of the recent settlement of an \$11 million sexual harassment involving a public accounting firm. The complaint was lodged in Federal Court in 2005 and both sides are reported to have amassed substantial legal bills.

\section{SEXUAL HARASSMENT LAWS}

According to the "Fair Employment Practices Manual," EEOC, 1991 two distinct types of activity can constitute sexual harassment:

Hostile Environment: Situations where the unwelcome sexual conduct of co-workers or supervisors interferes with an individual's ability to work or creates an intimidating or offensive atmosphere.

Quid pro quo: Situations where a workplace superior or coworker demands some degree of sexual favor and threatens to or actually does retaliate in a way that has a tangible effect on the working conditions of the harassment victim if he or she refuses to acquiesce.

The Equal Opportunity Commission, which carries the responsibility for enforcing federal discrimination laws, has issued guidelines which attempt to define the types of behavior that might fall into these classes: unwelcome sexual advances, requests for sexual favors, and other verbal or physical conduct of a sexual nature

\footnotetext{
${ }^{2}$ Though it is true that male CPAs can experience sexual harassment, the literature shows that a very small percentage of the population is affected. See Maypole (1986), Maypole and Skaine (1982), and Fitzgerald et al. (1988).

${ }^{3}$ Jennifer L. Berdahl, The Sexual Harassment of Uppity Women, Journal of Applied Psychology, Vol. 92, No. 2, 425-437, 2007.
} 
constitute sexual harassment when (1) submission to such conduct is either made explicitly or implicitly a term or condition of an individual's employment, (Quid Pro Quo) (2) submission to or rejection of such conduct by an individual is used as the basis for employment decisions affecting such individual, (Quid Pro Quo) or (3) such conduct has the purpose or effect of unreasonably interfering with an individual's work performance or creating an intimidating, hostile or offensive working environment (Hostile Environment.)

Although the EEOC regulations provide a starting point for understanding sexual harassment claims, court decisions provide the fullest guidance by applying these general rules to factual situations. In Meritor Savings Bank v. Vinson (1986), the Supreme Court recognized the "hostile environment" theory of sexual harassment as a form of sex discrimination prohibited by Title VII. ${ }^{4}$ However, prior to the passage of the Civil rights Act of 1991, there was no monetary remedy for hostile environment cases under federal law. The Civil Rights Act of 1991 added to existing civil rights laws such features as the right to a jury trial and the right to compensatory and, in some cases, punitive damages for job discrimination. For the first time, sexual harassment plaintiffs under Federal law are able to pursue damages for Title VII violations of up to $\$ 300,000$, exclusive of traditional remedies. In Harris v. Forklift Systems, Inc. (1993), the Supreme Court held that tangible psychological injury is not a necessary element of an abusive work environment claim. ${ }^{5}$ In 1994, the Supreme Court voted against applying the Civil Rights Act of 1991 retroactively to thousands of cases.

\section{THE STUDY}

Female public accounting professionals who were current members of the AICPA was the population of interest, and the AICPA provided a random sample of 2000 female members. ${ }^{6}$ The somewhat large sample size was selected for the following reasons:

- $\quad$ Studies involving sensitive subject matter often have a lower than normal response rate.

- $\quad$ Given the demands placed upon public accountants, the number of responses needed to be sufficient to assure a representative sample of the population.

- The Institute only provided a list of female AICPA members. Thus, it was expected that some of the respondents may no longer be employed in the public accounting sector.

Each participant was forwarded an instructional letter and a questionnaire (see appendix A). ${ }^{7}$ The questionnaire was visibly coded and the participant was assured anonymity. A second questionnaire was forwarded to non-respondents approximately six weeks later. Each questionnaire included a definition of sexual harassment in an attempt to improve the reliability of the responses. The questionnaire was designed with two purposes (areas of research) in mind, 1) to discover levels of incidence and 2) to gain anecdotal information/knowledge.

To collect the necessary data, the survey instrument was divided into four sections. Section 1 was designated "General Attitudes" and was composed of a list of opinion statements that, when answered, reflected the respondents' views on the definition and characteristics of sexual harassment. A five-point Likert scale (agreedisagree) was used with each statement in this part. Section 2 was comprised of numerous questions regarding incidence of sexual harassment as well as questions concerning location of harassment, and action taken by the victims. These questions could be answered by simply checking a Yes/No response, by selecting one or multiple alternatives, or by responding to a five-point Likert scale. The third section was designed to gather "demographic information" and allow classification of responses and group analysis. Lastly, respondents were given the opportunity to provide narrative comments, which were analyzed and categorized. This manuscript provides the demographic information and discusses the narrative comments included in the survey results. ${ }^{8}$

\footnotetext{
${ }^{4}$ Meritor Savings Bank v. Vinson, 477 U.S. 57, 106 S. Ct.2399 (1986).

${ }^{5}$ Harris V. Forklift Systems, Inc., 477 U.S. 5763 FEP 225 (1993).

${ }^{6}$ Though it is true that male CPAs can experience sexual harassment, the literature shows that a very small percentage of the population is affected. See Maypole (1986), Maypole and Skaine (1982), and Fitzgerald et al. (1988).

${ }^{7}$ To enhance validity and reliability, the questionnaire utilized in this study was originally developed by Maypole and Skaine and used in their 1983 study of blue collar workers. The instrument was modified slightly by Stanko and Schneider to make it more appropriate for their 1999 study of sexual harassment in the public accounting profession.

${ }^{8}$ Information regarding incidence can be found in Stanko et al 2009.
} 


\section{RESULTS}

Of the 2000 questionnaires mailed, 645 female AICPA members returned the survey instrument. Twentynine surveys were deemed unusable because of an inordinate number of incomplete responses. Another twenty-one surveys of the 2000 mailings were returned as undeliverable. This process generated 616 [645-29] valid responses for a $31 \%(616 / 2000)$ survey response rate. The response is considered adequate because it is greater than the norm of approximately $25 \% .^{9}$

Table I presents the sample respondents' demographic characteristics. The total response for respective demographic question does not total 616 because not all questions were answered in all survey responses. Thirty-four percent of the respondents were between 30-39 years of age, while 39\% were between 40-49 years old. Seventy percent of the respondents reported a bachelor's degree. Sixty-eight percent have more than 10 years of professional accounting experience. Approximately $31 \%(22 \%+9 \%)$ of the respondents were employed by national accounting firms with 50\% employed at the local level. This disparity was expected because local accounting firms employ a majority of AICPA members.

Table I: Demographic Summary $(\mathrm{N}=616)$

\begin{tabular}{|c|c|c|c|}
\hline Demographic & Category & Frequency & Percent \\
\hline \multirow[t]{5}{*}{ Age } & $20-29$ & 64 & $10 \%$ \\
\hline & $30-39$ & 205 & $34 \%$ \\
\hline & $40-49$ & 237 & $39 \%$ \\
\hline & 50 and over & $\underline{104}$ & $17 \%$ \\
\hline & & $\underline{610}$ & \\
\hline \multirow[t]{3}{*}{ Highest degree held } & Bachelors & 425 & $70 \%$ \\
\hline & Masters or above & $\underline{182}$ & $30 \%$ \\
\hline & & $\underline{\underline{607}}$ & \\
\hline \multirow[t]{5}{*}{ Years of professional accounting experience } & $0-2$ yrs & 4 & $1 \%$ \\
\hline & 3 to $5 \mathrm{yrs}$ & 67 & $11 \%$ \\
\hline & 6 to $10 \mathrm{yrs}$ & 122 & $20 \%$ \\
\hline & Over 10 yrs & $\underline{417}$ & $68 \%$ \\
\hline & & $\underline{\underline{610}}$ & \\
\hline \multirow[t]{5}{*}{ Type of firm affiliation } & National (big four) & 119 & $23 \%$ \\
\hline & National (other) & 51 & $9 \%$ \\
\hline & Regional & 99 & $18 \%$ \\
\hline & Local & $\underline{271}$ & $50 \%$ \\
\hline & & $\underline{\underline{540}}$ & \\
\hline \multirow[t]{5}{*}{ Area of specialization } & Audit & 222 & $39 \%$ \\
\hline & Tax & 239 & $42 \%$ \\
\hline & MAS & 13 & $2 \%$ \\
\hline & Other & $\underline{96}$ & $17 \%$ \\
\hline & & $\underline{\underline{570}}$ & \\
\hline \multirow[t]{5}{*}{ Present position } & Staff & 37 & $7 \%$ \\
\hline & Senior/In-Charge & 116 & $22 \%$ \\
\hline & Manager & 237 & $44 \%$ \\
\hline & Principal/Partner & $\underline{146}$ & $27 \%$ \\
\hline & & $\underline{536}$ & \\
\hline \multirow[t]{3}{*}{ Current marital status } & Single & 140 & $23 \%$ \\
\hline & Married & $\underline{470}$ & $77 \%$ \\
\hline & & $\underline{\underline{610}}$ & \\
\hline
\end{tabular}

\footnotetext{
${ }^{9}$ As a test of non-response bias, the returned questionnaires were grouped according to first or second mailings. Five-hundred and eighty-five questionnaires comprised the early group while 60 comprised the second. Mean responses for the early and late groups were compared with no significant t-statistic at the 0.05 level.
} 
In addition, the demographic survey response rate is approximately the same as Stanko and Schneider (1999), with one exception. Stanko and Schneider reported 40\% of the survey participants had 10 years or more of professional accounting experience. In the current survey, $60 \%$ of the participants have 10 years or more of professional accounting experience. In our opinion a greater percentage of more experienced professionals participating in the survey strengthen our findings. Experienced professionals are not likely to be concerned about their career options and advancement by responding to a survey on sexual harassment and offering objective statements.

Most of the respondents $(81 \%=39 \%+42 \%)$ indicated they specialized in auditing or tax services. Approximately $22 \%$ of the respondents were senior accountants and $44 \%$ were managers. Twenty-seven percent were partners with only $7 \%$ of the respondents falling under the staff classification. A low number of "staff" respondents may be credited to a variety of factors including short employment history, busy schedules, performing client services at remote locations, limited contact with firm personnel (therefore they might perceive the subject of sexual harassment as an unimportant issue), concern for carrier advancement by responding to the survey, etc. Seventy-seven percent of the respondents were married.

\section{SUMMARY AND DISCUSSION OF NARRATIVE COMMENTS}

Approximately 18\% (111/616) of the respondents provided narrative comments, and 96 of the 111 comments were classifiable. The comments are important because: 1) they provide specific incidences of women who have experienced sexual harassment in public accounting as well as other viewpoints, and 2) they are fairly recent in nature, as the initial questionnaire mailing was in 2004. The comments were classified into five categories, as follows:

1. Described incidents or lack thereof of sexual harassment (38 or 39\%)

2. Discussed sexual discrimination versus sexual harassment (22 or 23\%)

3. Offered advice on how women can discourage or prevent future incidents of harassment or described their organization's policy on sexual harassment (19 or 20\%)

4. Described the current versus the past climate of sexual harassment (16 or 16\%)

5. Described what does or does not constitute sexual harassment (2 or $2 \%)$

One comment discussed both the current versus past climate and sexual discrimination versus sexual harassment, and was therefore counted in both categories.

\section{INCIDENCE}

Thirty-nine percent of the narrative comments either described sexual harassment incidents that took place or a lack of such incidents. In a few cases, negative experiences resulted in respondents either leaving public accounting or changing positions. For example, one woman wrote:

"Sexual harassment and discrimination are very serious problems in public accounting and need to be addressed for women to remain employed in the industry. I like working in public accounting, but I left because the sexual harassment and discrimination became too overwhelming. I make no regrets selecting accounting as a profession; however, I profoundly regret my time spent in public accounting. I don't recommend that women select public accounting as profession, rather I recommend accounting. Additionally, I strongly believe women should be informed of the harassment and discrimination issues in public accounting before entering the profession. My hope is that colleges are providing this knowledge to young women."

Another woman wrote:

"I feel sexual harassment is extremely prevalent and is not going anywhere. I see it all of the time and have experienced it myself several times. Always by a man to a woman and most of the time the man is married. I do not think that the man is always using sex as a power in the job but more likely using sex just to have sex (because they think they can or they think they are wanted). It is very frustrating because as a woman, I am too embarrassed to 
report anything (especially if it's my boss). And, no matter what, the discomfort does not go away. It is terrible for the young, idealistic girls out of college in the accounting profession. The first time it happened to me, I was shocked - now I am used to it (8 years later). How sad. I am only 30 years old."

Other respondents wrote:

"I experienced all of my sexual harassment or similar experiences during my Big 4 career; and virtually none outside of my Big 4 career;" "Why I didn't tell? The embarrassment I would feel if my family and my children knew; the damage my professional reputation would suffer if my clients and co-workers knew; and the damage my personal life would suffer if my fiancé knew, were all strong enough reasons for me to not make the sexual harassment experience public. Why didn't I quit? As a divorced single mom, I needed a firm that would be flexible with my schedule, and my firm is flexible with parents' schedules. Only one of the partners would know the real reason I quit. The others would only see a senior employee, whose education they paid for, leaving for a vague reason. I was afraid of the loss of professional and personal credibility I would suffer."

A number of respondents took the opposite view, that sexual harassment is not a problem in public accounting and that training for how to deal with sexual harassment and prevent it from occurring is adequate and effective. Remarks reflecting this viewpoint included the following:

"I had no problems in public accounting. I have had issues with one man who was my supervisor in a private firm. $N O$ woman ever received responsibility or a fair workload under his supervision;" "I have not known of any sexual harassment cases at my firm in the 7 years I have been employed here;" "I don't know if the accounting profession has adequately addressed the issue of sexual harassment because I have never been exposed to it;" "I believe my current firm adequately addresses sexual harassment through annual seminars and open policies. I do not believe this to be the case at all firms;" "I was fortunate to never have encountered such unpleasant situations. I worked with very professional individuals - at Coopers \& Lybrand, LLP and the behavior wouldn't have been tolerated in the group I worked in;" I am lucky that I work with a group of co-workers and clients. I have never had a harassment problem. Our firm would absolutely not tolerate such behavior."

Some respondents cited incidents with firm partners and clients, as follows: "I feel that most sexual harassment would be from two parties - older men and clients - because most young to middle age men who work in accounting firms are aware of sexual harassment;" "(in) my current firm one partner was sued by a former employee for sexual harassment. The partner settled out of court with her;" "Managing partner was the offender. Other partners tolerated his behavior toward women;" "When sexually harassed by a client, I reported the incident any my firm did nothing about it. I was pulled from the engagement and that was all that was done. I will not report the current situation with my boss because I need this job and nothing will happen except me losing my position here. He's a known sexual harasser but no one does anything. He's been sued 3 times that I know of and settled out of court for minimal damages;" "I have answered these questions thinking of my recent experience in the Big 4. I am now self-employed, but feel the big firms were/are trying hard to address these problems. Unfortunately, many of the complaints I have heard had to do with client personnel and that is not easily handled;" "Never had a problem in the accounting industry but have seen it at clients."

\section{DISCRIMINATION VERSUS HARASSMENT}

Many of the narrative comment respondents feel that sexual discrimination in public accounting is just as important an issue or an even more important issue than sexual harassment. This was clearly reflected in the comments, some of which follow:

"Actually sexual discrimination is more of a problem than sexual harassment. It was quite evident that women weren't given the advancement opportunities that men were at both public accounting firms I worked at despite promoting otherwise. There have always been clients, co-workers and bosses who promoted a less than professional atmosphere. In my case it never crossed the line to the physical aspect of sexual harassment. It has also seemed to improve from my first stint in public accounting to my second;" "Discrimination, however, is still as bad as it ever was. Women are not promoted as quickly as men, not many women partners, etc.;" "Add a study on 
age discrimination;" "Sexual discrimination is more of a problem than sexual harassment. Look at all Big 4 Accounting firms and you'll see it quite starkly. Sexual discrimination is the biggest problem for women in the Accounting profession. Women in Big 4 or Regional always get pushed into non-profit work where there is no money after you leave public;" "I feel, in my experience, it's not sexual harassment that is the problem, but gender issues - women look at and approach issues differently than men do, but because I don't fit "the mold", I'm not capable of higher level performance;" "I think people are confusing sexual harassment and discrimination terms. Has the accounting professional dealt with discrimination in a predominately male workforce?"

Several respondents made comments that were related to starting a family, as follows: "I worked for a local firm very successfully for several years, until the arrival of a new partner. He told me that he didn't hire female accountants, because they "just have babies and then quit;" after about a year of enduring his attitudes and tirades, I left and began my own practice;" "After I had been hired, I was told that the owners were concerned with my recent marriage and that since I was Irish and Catholic that I would probably "make babies" and leave. I left that company a few months ago and do not feel the negativity towards women in my new place. I got really depressed at one other place and discussed with my boss what I could do and he said "nothing;" "I had low expectations after being informed by a Big 8 representative, speaking to my auditing class, that it would take women longer to make partner. Why? Because they wanted to make sure the woman was "serious" and wouldn't leave to have babies. There's a welcoming attitude to the workplace."

Some respondents commented on how compensation and/or promotion are affected by sexual discrimination: "I think another major concern is discrimination of females by male counterparts. Still concerned about equal pay;" "I think the point of power is the pay scale. How many women CPA's receive the same pay as their counterparts? Almost none. This is a form of sexual empowerment for the males too!" "Two men have been made partners ahead of me. One started around the same time I did, but the second was hired several years after me. I have been with this firm since 5/91;" "A lot of pressure that you must dramatically outperform the guys to be noticed for advancement while being noticed in general prompts gender biased remarks/actions."

Other respondents commented on how the traditional nature of public accounting creates problems for women: "I believe the traditional nature of the accounting profession makes it easier for sexual harassment and discrimination to take place; that is one factor that affected my choice of working in industry;" "I think the biggest issue is trying to fit in with "the guys". Either you put up with the sexual content of interactions or you don't. If you do it's uncomfortable but you may be accepted as "one of the guys." If you don't, you're less likely to be invited to join the guys for lunch, etc. and lose the opportunity to bond with people you work with as a team;" "I believe that the accounting profession, as I experienced it during internship and two years of service, has problems with plain harassment toward women;" "I have found more of a problem in being treated poorly by male supervisors when my male counterparts were not. Specifically, I have been assigned demeaning work (typing, file, faxing) repeatedly while males performed more challenging work. If find that sexual prejudice is prevalent in the smaller firms." One respondent summed up her feelings with the following statement: "Sexism is still a "BIG" issue."

\section{DISCOURAGEMENT AND PREVENTION}

About one-fifth of the narrative comment respondents discussed prevention of sexual harassment. A few respondents stated that training exists, but that complaints are not taken seriously. These comments are as follows:

\footnotetext{
"Company has made adequate provisions, but does not take complaints seriously;" "Management has taken adequate provisions. Formally, the company has all the written policies and procedures and has stated that it does not accept such behavior. However, culturally, it is still somewhat viewed as a "boys" club and because only men have the highest management roles, there is little sympathy for what may be occurring. Publicly they say they are against it. Privately they question whether we need "thicker skins" and whether we are overly sensitive to random comments;" "On the surface "yes"-policies are in place and enforced if management is aware; "no" because individual attitudes remain in place;" "Many men say or do things that are degrading without even being aware that they are offensive. More education is needed. It is difficult to say anything to clients."
} 
Several respondents stated that legal liability of the firm is more of a concern than the victims of sexual harassment, as follows:

"I think that large firms are more concerned about protecting the firm from liability than their employees who may have been victims or violators;" "Management's concern is more toward the potential legal liability rather than maintaining the dignity of all employees in the workplace."

Other respondents stated that sexual harassment prevention has received adequate attention, as follows:

"I agree strongly with the level of attention this matter gets at this firm - all members are to act professionally and it is expected and assumed that we will. The culture here is relaxed, friendly, and serious when it needs to be;" "I feel our firm has taken strong actions within the firm, but sexual harassment by/at a client is still a touchy issue."

Finally, a few respondents commented that additional sexual harassment and "anti-harassment" training is needed, as follows: "I think that sexual harassment should be discussed in all firm's employee manuals; and that it will not be tolerated and those who commit it will be prosecuted accordingly;" "While I'm no longer in public accounting, I believe there is a need for specific anti-harassment (not only sexual) [training] in the profession. The local firms particularly may have the least availability to training. It would be prudent to offer anti-harassment training as CPE;" "AICPA should be a resource for in-house training on the topic."

One respondent had such strong feelings about sexual harassment and discrimination in public accounting that she does not recommend it as a career for females: "Sexual harassment and discrimination are very serious problems in public accounting and need to be addressed for women to remain employed in the industry. I like working in public accounting, but I left because the sexual harassment and discrimination became too overwhelming. I make no regrets selecting accounting as a profession; however, I profoundly regret my time spent in public accounting. I don't recommend that women select public accounting as profession, rather I recommend accounting. Additionally, I strongly believe women should be informed of the harassment and discrimination issues in public accounting before entering the profession. My hope is that colleges are providing this knowledge to young women." Another wrote: "Accountants seem to bury their heads in the sand and don't like to believe the employees. They have more of a tendency to believe and want to keep the clients. (\$\$\$) Employees seem to be expendable but not clients."

\section{CURRENT VS. PAST CLIMATE}

Some of the respondents commented on the current versus past climate of sexual harassment in public accounting, and most of those comments indicated that there has been an improvement in both incidences and training during the past $15-20$ years. Some of the comments were as follows:

"I think this profession is changing. There are a few older people that have a hard time accepting women in the workplace, but for the most part I never notice a difference between men and women at work and have never experienced harassment;" "Isolated occurrence early in my career. Much has changed in the last 20 years to eliminate issues;" "I have not practiced public accounting for almost twenty years. When I left [sexual harassment] was not [addressed]. At my current place of employment, sexual harassment is not tolerated and has been adequately addressed;" "The problem has gotten much better over the last 15 years - training in sexual harassment, in general an awareness and better environment. Discrimination, however, is still as bad as it ever way. Women are not promoted as quickly as men, not many women partners, etc.;" "There are still some "old school" partners, but for the most part things are improving." "The profession has changed considerably in the 14 years I have been in it. I think a lot is due to significant increase of women in the workforce;" "I experienced sexual harassment during my public accounting career over 15 years ago. If it had happened today, I would have reported it, given the increased awareness in today's society." 


\section{WHAT CONSTITUTES SEXUAL HARASSMENT}

Respondents who commented on what constitutes sexual harassment cited the use of sexual comments or jokes, as follows: "Harassment also takes the form of derogatory remarks over a female taking the "mommy track;" hence no promotions, lower raises, etc." One respondent stated "I do not consider vulgar language and jokes that are not tasteful to be sexual harassment. Further, I believe women abuse the use of the term." Finally, one respondent stated that "This questionnaire appears to focus on sexual harassment of women by men, but it is also possible that women in the profession make comments and advances to men."

\section{CONCLUSIONS, IMPLICATIONS AND RECOMMENDATIONS}

Though the findings reported here corroborate previous research outcomes, this study is subject to several limitations. First, the male accounting population was excluded from this research for reasons previously stated (see note 2). Second, a more efficient sampling process could have been selected but was not available through the AICPA at the time of this study. Third, the results include what subjects perceive and may not necessarily be what actually takes place on the job. Finally, not all females employed in public accounting are members of the Institute.

Subject to these limitations, the study provides evidence that suggests public accounting firms continue to be exposed to significant within-firm risk, as well as with associated clients. Female accounting professionals at all responsibility levels continue to experience or have experienced harassing behavior. Furthermore, while much of the harassment is verbal, neither the firm's office, client's office, or firm/client social gatherings provide a "safe" professional environment.

Statistical analysis of the "general attitude" statements and a review of the narrative comments provided by respondents indicate that sexual harassment remains an issue in public accounting, despite the fact that progress has been made in recent years. The narrative comments revealed the following:

- $\quad$ Sexual harassment most often takes the form of inappropriate comments or jokes.

- $\quad$ The incidence of sexual harassment in public accounting is mixed. Comments ranged from sexual harassment being extremely prevalent to not being a problem in public accounting.

- $\quad$ As for prevention, policies have been put in place but are not always enforced; and legal liability of the firm may be more of a concern than the victims of sexual harassment.

- $\quad$ There has been a general improvement in both incidences and training during the past 15-20 years.

- $\quad$ Sexual discrimination may be just as important an issue if not a more important issue than sexual harassment, and may need to be addressed by the profession in the future.

In an attempt to improve the workplace environment (46\% of the respondents stated the issue of sexual harassment needs to be better addressed by the accounting profession), firms must continue to establish and enforce effective, well-communicated policies denouncing harassing behavior. This policy must be sensitive to the evolving sexual harassment environment and must require "enlightened" compliance. Lines of communication must be open so as to understand both male and female interpretations of potentially harassing behaviors and the firm must be ready to enforce the policy when necessary. Furthermore, employees must understand what actions constitute sexual harassment and how to file complaints against alleged offenders. Victims also need assurance that claims will be properly reviewed and confident no repercussions will arise because of the filings.

Further, the law provides remedies that allow relief in many cases of sexual harassment. The Civil Rights Act of 1991 increases the potential liability for employers found guilty of violating Title VII. Sixty-one percent of the respondents indicated familiarity with the Civil Rights Act of 1991, but how broad is this understanding? What about the remaining thirty-nine percent of the respondents? Obviously, their lack of knowledge can be perilous as well. The legal issues surrounding sexual harassment are very complex. According to 1991 EEOC guidelines, employers are encouraged to take all steps necessary to prevent sexual harassment from occurring, such as affirmatively raising the subject, expressing strong disapproval, developing appropriate sanctions, informing employees of their right to raise and how to raise the issue of sexual harassment under Title VII, and developing methods to sensitize all concerned (EEOC, 1991). Public accounting firms must continue to include regular and mandatory sexual 
harassment training among their Continuing Professional Education (CPE) offerings. At such sessions employees should be made aware that the firm will not tolerate sexual harassment misconduct.

Additionally, the AICPA should establish a separate "Rule" on sexual harassment accompanied by detailed interpretation including illustrative examples. Presently, AICPA Interpretation 501-2 of its Code of Professional Conduct states that discrimination based on race, color, religion, sex, age or national origin in hiring, promotion or salary practices is presumed to constitute an act discreditable to the profession.

\section{AUTHOR INFORMATION}

Gerald J. Miller holds a Ph.D. from the University of Kentucky, an MBA from Murray State University and a BS from Canisius College. He is also a Certified Public Accountant, Illinois (inactive) and a Certified Government Financial Manager. Dr. Miller's work experience includes five years in private sector accounting, ten years in government auditing and fifteen years in academia. His research interests are in the areas of governmental accounting and accounting education. He currently serves as the Chair of Accounting and Information Systems at the College of New Jersey.

Brian B. Stanko holds a Ph.D. from the University of Kentucky, an MBA and a BS from Eastern Illinois University. $\mathrm{He}$ is a registered Certified Public Accountant (Illinois.) Dr. Stanko's work experience includes five years in accounting and financial reporting and twenty years in academia. His research interests are in the areas of cash flow analysis, annual report analysis, corporate reporting and accounting education. He currently serves as the Chair of the Accounting and Business Law Department at Loyola University Chicago.

Ellen L. Landgraf holds a Ph.D. from the University of Illinois at Chicago, an MBA from Northern Illinois University and a BBA from Loyola University Chicago. She is a registered Certified Public Accountant (Illinois.) Dr. Landgraf's work experience includes positions at the IRS and in public accounting (both Big Eight and small practitioner) prior to her over thirty years in academia. Her research interests are in the areas of executive compensation, corporate governance and social responsibility, corporate disclosure and reputation and ethics and accounting.

\section{REFERENCES}

1. Acken, B., St. Pierre, K. and P. Veglahn: 1991, "Limiting Sexual Harassment Liability", The Journal of Accountancy, 171, 42-47.

2. American Institute of Certified Public Accountants: 2005, "A Decade of Changes in the Accounting Profession: Workforce Trends and Human Capital Practices", New York: AICPA.

3. Berdahl, Jennifer L: 2007, "The Sexual Harassment of Uppity Women”, Journal of Applied Psychology, 92, 425-437.

4. Center for Women and Work: 2002 "Sexual Harassment in the Workplace: Research in Brief”, Rutgers University, 2, 1-4.

5. $\quad$ Elliott, Polly B: 1992 "Sexual Harassment Filings Jump”, Chicago Tribune, Section 1, 4.

6. Equal Employment Opportunity Commission: 1991 "Fair Employment Practices Manual", Equal Employment Opportunity Commission, Washington, D.C.

7. Fitzgerald, L. E., Shullman, S. S., Bailey, N., Richards, M: 1988 "The Incidence and Dimensions of Sexual Harassment in Academia and the Workplace," Journal of Vocational Behavior, 32, 152-175.

8. Foy, Norman F.: 2000, "Sexual Harassment Can Threaten Your Bottom Line", Strategic Finance, 82.

9. Hooks, Karen L.: 1992, "Gender Effects and Labour Supply in Public Accounting: An Agenda of Research Issues", Accounting, Organizations and Society, 17, 343-366.

10. Oppenheimer, David B.: 1995-96, "Exacerbating the Exasperated: Title VII Liability of Employers for Sexual Harassment" Cornell Law Review, 81.

11. Ilies R., Hauserman N., Schwochau S, and J. Stibal: 2003, "Reported Incidence Rates of Work-Related Sexual Harassment in the United States: Using Meta-Analysis to Explain Reported Rate Desparities", Personnel Psychology, 56, 607-631. 
12. Lehman, Cheryl R.: 1992, “'Herstory' in Accounting: The First Eighty Years”, Accounting, Organizations and Society, 17, 343-366.

13. Loft, Anne: 1992, “Accountancy and the Gendered Division of Labour: A Review Essay,” Accounting, Organizations and Society, 17, 367-378.

14. Maypole, Donald E.: 1986, "Sexual Harassment of Social Workers at Work: Injustice Within?” Social Work 31, 29-34.

15. Maypole, Donald E. and Rosemary Skaine: 1983, "Sexual Harassment in the Workplace" Social Work, 28, 385-389.

16. Maypole, Donald E. and Rosemary Skaine: 1982, "Sexual Harassment and Blue Collar Workers”, Journal of Sociology and Social Welfare, 9, 682-695.

17. Stanko, B., Werner, C. and T. Zeller: 2009, "Sexual Harassment in the Public Accounting Profession: A Revisit", Journal of Accounting, Ethics \& Public Policy, 10:2, 177-211.

18. Stanko, Brian B. and Mark Schneider: 1999, "Sexual Harassment in the Public Accounting Profession?" Journal of Business Ethics, 18, 185-200.

19. Smith, Wray E. and Shirley Howell: 1991, "Sexual Harassment in the Workplace", Alabama Lawyer, July, 194-199.

20. Venkataraman I., Raghunandan, K., and D. Rama: 2005, “Gender Differences in Perceptions of Accounting Firm Alumni”, Managerial Auditing Journal, 20, 449-459. 


\section{APPENDIX A}

\section{Survey Instrument}

June 25, 2004

AICPA Accounting Professional:

This is a request for your participation in a national accounting research project supported by the AICPA. As members of the accounting profession, we perform our responsibilities with integrity and honesty. While we hope that our profession is unaffected, evidence suggests that female accounting professionals may experience some form of sexual harassment* sometime during their careers.

The purpose of this study is to address this socially unacceptable behavior. Your name was one of 2,000 drawn from a random sample by the Institute. Your response to the enclosed questionnaire will provide relevant information essential to the ongoing success of our profession. Each questionnaire is visibly coded and used for group comparison only. I assure you no individual information will be revealed.

Please complete the entire questionnaire, as unanswered questions detract from the usefulness of the instrument. Pretesting has indicated the questionnaire should take no longer than 15 minutes of your time to complete. A selfaddressed, postage-paid envelope is included for your mailing convenience. Thank you for your prompt response.

Sincerely,

B. Stanko, Ph.D., CPA

C. Werner, JD, CPA

Enclosure

* See Stanko and Schneider, "Sexual Harassment in the Public Accounting Profession", Journal of Business Ethics, January 1999.

\section{Questionnaire on Sexual Harassment}

Instructions: For the items listed below circle the number which most accurately reflects your opinion.

$\mathbf{S A}=$ strongly agree; $\mathbf{A}=$ agree; $\mathbf{N}=$ neutral $; \mathbf{D}=$ disagree; $\mathbf{S D}=$ strongly disagree.

General attitudes:

\begin{tabular}{|c|c|c|c|c|c|}
\hline SA & $\mathbf{A}$ & $\mathbf{N}$ & D & SD & \\
\hline 1 & 2 & 3 & 4 & 5 & $\begin{array}{l}\text { 1. Often when a person sexually harasses another, exerting } \\
\text { power over the other is more important than gratification. }\end{array}$ \\
\hline 1 & 2 & 3 & 4 & 5 & 2. Sexual harassment and sexism are the same. \\
\hline 1 & 2 & 3 & 4 & 5 & $\begin{array}{l}\text { 3. When one person uses authority and power to force another } \\
\text { into unwarranted sexual relations, she/he uses a form of rape. }\end{array}$ \\
\hline 1 & 2 & 3 & 4 & 5 & $\begin{array}{l}\text { 4. Unwanted sexual behavior toward women is sexual } \\
\text { harassment. }\end{array}$ \\
\hline 1 & 2 & 3 & 4 & 5 & 5. Women in all classes of society are sexually harassed. \\
\hline
\end{tabular}




$\begin{array}{lllll}1 & 2 & 3 & 4 & 5 \\ 1 & 2 & 3 & 4 & 5 \\ 1 & 2 & 3 & 4 & 5 \\ 1 & 2 & 3 & 4 & 5 \\ 1 & 2 & 3 & 4 & 5\end{array}$

6. The man is at fault most of the time in sexual harassment cases.

7. Women tolerate sexual harassment because they feel little can be done.

8. The major function of sexual harassment is to preserve the dominance of males over females.

9. Most bosses are not willing to take action to eliminate sexual harassment.

10. Most cases of sexual harassment are not reported to bosses or other administrators.

Incidence:

Instructions: For the following questions place an " $\mathrm{X}$ " in the box which most accurately reflects your position.

11. I know women who have been sexually harassed in the accounting work setting.

\begin{tabular}{|c|c|c|c|c|}
\hline \multicolumn{5}{|r|}{ (Check more than one if } \\
\hline \multirow[t]{7}{*}{ Type } & $\square$ & Sexually vulgar language & $\square$ & Chilling atmosphere \\
\hline & $\square$ & Remarks about physical anatomy & $\square$ & $\begin{array}{l}\text { Job altered without } \\
\text { justification }\end{array}$ \\
\hline & $\square$ & Derogatory gender comments & $\square$ & Unwanted touching \\
\hline & $\square$ & Display of lewd/nude materials & $\square$ & $\begin{array}{l}\text { Unwanted intercourse } \\
\text { with consent }\end{array}$ \\
\hline & $\square$ & Negative performance assessment & $\square$ & Sexual activity for a favor \\
\hline & $\square$ & Client performance complaint & $\square$ & Rape \\
\hline & & & $\square$ & Other \\
\hline
\end{tabular}

12. Where do you believe sexual harassment is most likely to occur?

(Check more than one if necessary)

When female accountants are out of town on client business

At or after national or regional training meetings

At or after local training meetings

At or after firm social gatherings

At or after social situations with clients including business lunches or dinners

In the firm's offices

In client's offices

Other

13. Have you personally experienced any form of sexual harassment in the accounting work place?
YES
$\square \mathrm{NO}$
If no, please proceed to Question \#20. 
14. I feel I have been the victim of sexual harassment from a boss.

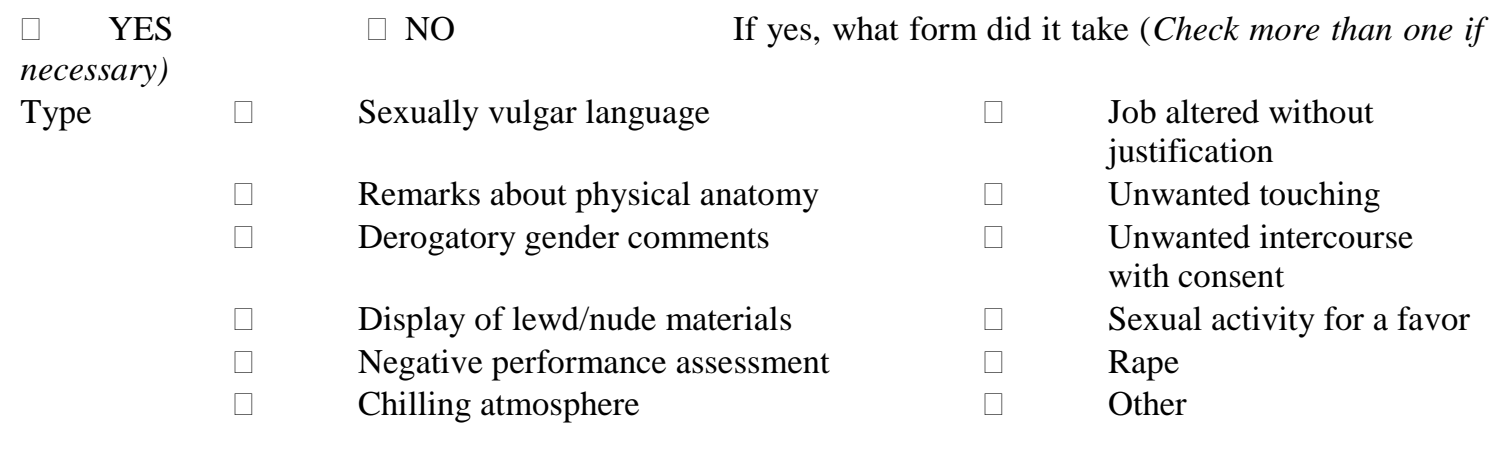

15. I feel I have been the victim of sexual harassment from a coworker.

\begin{tabular}{|c|c|c|c|c|}
\hline$\square$ & YES & $\begin{array}{l}\text { If yes, } \\
\text { necessc }\end{array}$ & dic & ke (Check more than one if \\
\hline Type & $\square$ & Sexually vulgar language & $\square$ & Unwanted touching \\
\hline & $\square$ & Remarks about physical anatomy & $\square$ & $\begin{array}{l}\text { Unwanted intercourse } \\
\text { with consent }\end{array}$ \\
\hline & $\square$ & Derogatory gender comments & $\square$ & Sexual activity for a favor \\
\hline & $\square$ & Display of lewd/nude materials & $\square$ & Rape \\
\hline & $\square$ & Chilling atmosphere & $\square$ & Other \\
\hline
\end{tabular}

16. I feel I have been the victim of sexual harassment from a client.

\begin{tabular}{|c|c|c|c|c|}
\hline$\square$ & & $\begin{array}{l}\text { If yes, } \\
\text { necess }\end{array}$ & \multicolumn{2}{|c|}{$\begin{array}{l}\text { If yes, what form did it take (Check more than one if } \\
\text { necessary) }\end{array}$} \\
\hline \multirow[t]{5}{*}{ Type } & $\square$ & Sexually vulgar language & $\square$ & Unwanted touching \\
\hline & $\square$ & Remarks about physical anatomy & $\square$ & $\begin{array}{l}\text { Unwanted intercourse } \\
\text { with consent }\end{array}$ \\
\hline & $\square$ & Derogatory gender comments & $\square$ & Sexual activity for a favor \\
\hline & $\square$ & Display of lewd/nude materials & $\square$ & Rape \\
\hline & $\square$ & Client performance complaint & $\square$ & Other \\
\hline
\end{tabular}

17. If you experienced sexual harassment in the workplace, to whom did you report it?

$\begin{array}{llll}\text { Type } \square \quad \text { Did not report } & \square & \text { Firm administrator / boss } \\ \square & \text { Spouse, if married } & \square & \text { Law enforcement official } \\ \square & \text { Friend, not at work } & \square & \text { Private attorney } \\ \square & \text { Coworker } & \square & \begin{array}{l}\text { State human rights commission } \\ \text { representative }\end{array} \\ & \text { Supervisor } & \end{array}$

18. If you reported it, were you satisfied with the action taken on your behalf?
YES
$\square \mathrm{NO}$

19. Have you contemplated leaving the organization because of this occurrence?
YES
$\square$ NO

20. What do you feel is management's view of sexual harassment problems in your company?

Very concerned $\square$ Concerned $\square$ Unknown $\square$ Unconcerned $\square$ Very unconcerned 
21. The management of our company has made adequate provisions for dealing with the sexual harassment problem.
$\square \quad$ Strongly agree
Agree
Undecided
Disagree $\square$ Strongly disagree

22. I am familiar with current laws such as the Civil Rights Act of 1991 which allows parties to collect compensatory punitive damages for intentional discrimination.
$\square \quad$ YES
$\square \mathrm{NO}$

23. Do you feel the issue of sexual harassment has been adequately addressed by the accounting profession during you career in public accounting?

$\square \quad$ YES $\quad \square$ NO

24. Additional Comments:

Demographic information:

25. Age: $\square$ 20-29 $\square$ 30-39 $\square$ 40-49 $\square 50$ and over

26. Highest degree held: $\quad \square$ Bachelors $\square$ Masters and above

27. Years of professional accounting experience: $\square \quad 0-2 \quad \square \quad 3-5 \quad \square \quad 6-10 \quad \square$ over 10

28. Type of firm affiliation: $\square$ National (big-four) $\quad \square$ National (other) $\square$ Regional $\square$ Local

29. Area of specialization: $\square$ Audit $\square$ Tax $\square$ MAS $\square$ Other

30. Present position: $\square$ Staff $\square$ Senior/In-charge $\square$ Manager $\square$ Principle $\square$ Partner

31. Current marital status: $\square$ Single $\square$ Married

Thank you very much.

\section{NOTES}

